\title{
NET METHYLMERCURY PRODUCTION IN 2 CONTRASTING STREAM SEDIMENTS AND ASSOCIATED ACCUMULATION AND TOXICITY TO PERIPHYTON
}

\author{
Jaclyn E. Klaus, $†$ Chad R. Hammerschmidt, $* \dagger$ David M. Costello,$\ddagger$ and G. Allen Burton, Jr. $\oint$ \\ $\dagger$ Department of Earth \& Environmental Sciences, Wright State University, Dayton, Ohio, USA \\ $\ddagger$ Department of Biological Sciences, Kent State University, Kent, Ohio, USA \\ $\S$ School of Natural Resources \& Environment, University of Michigan, Ann Arbor, Michigan, USA
}

(Submitted 6 October 2015; Returned for Revision 15 November 2015; Accepted 3 December 2015)

\begin{abstract}
Periphyton uptake of bioaccumulative methylmercury $(\mathrm{MeHg}$ ) may be an important entryway into the food web of many stream ecosystems where periphyton can be dominant primary producers. The net production of $\mathrm{MeHg}$ in stream sediment, its bioaccumulation in periphyton, and the potential toxicity of divalent $\mathrm{Hg}(\mathrm{Hg}[\mathrm{II}])$ and $\mathrm{MeHg}$ in sediment to periphyton were investigated with a 67-d in situ incubation experiment using chemical exposure substrates containing either a fine-grained, organic-rich or a sandy, low-organic sediment, each amended with varying concentrations of mercuric chloride. Methylmercury was produced in sediment, and concentrations increased with greater amounts of added $\mathrm{Hg}$ (II); however, the net production of $\mathrm{MeHg}$ was inhibited in the highest $\mathrm{Hg}(\mathrm{II})$ treatments of both sediments. The range of total $\mathrm{Hg}$ concentrations that inhibited $\mathrm{MeHg}$ production was between approximately $80000 \mathrm{ng} \mathrm{Hg}$ and $350000 \mathrm{ng} \mathrm{Hg}$ per gram of organic matter for both sediments. Periphyton colonizing substrates accumulated MeHg in proportion to the concentration in sediment, but periphyton exposed to the sandy sediment accumulated approximately 20 -fold more than those exposed to the organic-rich sediment relative to sediment $\mathrm{MeHg}$ concentrations. Toxicity of either $\mathrm{Hg}$ (II) or MeHg to periphyton was not observed with either periphyton organic content, net primary production, or respiration as endpoints. These results suggest that in situ production and bioaccumulation of $\mathrm{MeHg}$ in stream ecosystems can vary as a function of sediment characteristics and $\mathrm{Hg}$ (II) loadings to the sediment. Environ Toxicol Chem 2016;35:1759-1765. (C) 2015 SETAC
\end{abstract}

Keywords: Mercury Methylmercury Bioavailability Sediment chemistry

\section{INTRODUCTION}

Mercury $(\mathrm{Hg})$ is a pervasive environmental contaminant that enters stream ecosystems through weathering of natural deposits, discharge from point sources, and atmospheric deposition from natural and anthropogenic emission sources. Within stream ecosystems, complexes of divalent $\mathrm{Hg}(\mathrm{Hg}[\mathrm{II}])$ can be transformed to methylmercury ( $\mathrm{MeHg}$ ), which bioaccumulates and biomagnifies within aquatic food webs $[1,2]$ to levels that may be harmful to some organisms, particularly piscivorous wildlife [3,4] and humans who eat fish [5]. Methylation of $\mathrm{Hg}$ (II) to $\mathrm{MeHg}$ can occur abiotically [6], but most $\mathrm{MeHg}$ production is thought to occur biologically [7], with the mechanism recently attributed to proteins associated with the $h g c A B$ gene cluster [8] that is present in a variety of anaerobic microorganisms $[9,10]$. Periphyton (i.e., a complex community of algae, bacteria, microinvertebrates, and detritus attached to submerged surfaces) are known to be capable of $\mathrm{Hg}$ methylation [11-14], and this organic-rich material can either scavenge or bioaccumulate $\mathrm{MeHg}$ from water [15]. Periphyton uptake of $\mathrm{MeHg}$, whether from in situ production or other sources in the watershed, may be an important entryway into the food web of many stream ecosystems where periphyton can be dominant primary producers [16,17].

Multiple studies have examined $\mathrm{Hg}$ methylation by a variety of periphyton communities, but very few studies have examined the potential for toxicity of either total $\mathrm{Hg}$ or $\mathrm{MeHg}$ to periphytic communities. Periphyton are sensitive to environmental

This article includes online-only Supplemental Data

* Address correspondence to chad.hammerschmidt@wright.edu

Published online 4 December 2015 in Wiley Online Library

(wileyonlinelibrary.com).

DOI: $10.1002 /$ etc. 3324 stressors such as either enrichment or deficit of nutrients and metals [18] and pesticides [19] and are useful for assessing the ecological health of aquatic systems [16,20]. Many controlled chemical exposure studies have been conducted on both native and cultured periphyton, but it has been suggested that the best method to assess contaminant effects on periphyton is by use of in situ chemical exposure substrates under natural conditions in stream environments [21].

For the present study we conducted an in situ experiment with chemical exposure substrates to investigate 1) net production of $\mathrm{MeHg}$ in 2 geochemically dissimilar stream sediments in southwest Ohio, 2) accumulation of $\mathrm{MeHg}$ and total $\mathrm{Hg}$ in periphyton naturally colonizing the substrates, and 3) the potential toxicity of $\mathrm{MeHg}$ and total $\mathrm{Hg}$ effluxing from sediment to periphyton. This was done by serially adding $\mathrm{HgCl}_{2}$ to 2 contrasting sediment types, 1 that was fine-grained and organicrich and another that was sandy with low organic content. The sediment samples were incubated for $67 \mathrm{~d}$ in chemical exposure substrates in a southwest Ohio stream with fritted glass lids that allowed for solute exchange and colonization by natural stream periphyton [21]. At the end of the incubation, we quantified $\mathrm{MeHg}$ and total $\mathrm{Hg}$ concentrations in sediment and periphyton colonizing the chemical exposure substrates as well as measured periphyton organic content and metabolic activity (net primary production and respiration) as endpoints of toxicity from the exposures.

\section{MATERIALS AND METHODS}

\section{Experimental design}

The exposure design of the present study followed that of Costello and colleagues [21], which was adapted from prior investigations using nutrient-diffusing substrates [22,23]. Sandy, low-organic (1\% loss on ignition, acid volatile sulfide 
$[\mathrm{AVS}]=0.4 \mu \mathrm{mol} / \mathrm{g}$ dry wt) sediment was collected from Sugar Creek (Sugarcreek Township, OH, USA) and fine-grained, organic-rich ( $17 \%$ loss on ignition; AVS $=4.8 \mu \mathrm{mol} / \mathrm{g}$ dry $\mathrm{wt})$ sediment from Warden Ditch (Fairborn, OH, USA). Four liters of sediment from both streams were transported to Wright State University, where they were homogenized with a stainless-steel mixer and each sediment was divided into 5 high-density polyethylene $500-\mathrm{mL}$ bottles. Ambient concentrations of total $\mathrm{Hg}$ averaged $7.3 \pm 1.2 \mathrm{ng} / \mathrm{g}$ dry weight in Sugar Creek sediment and $87 \pm 5 \mathrm{ng} / \mathrm{g}$ in Warden Ditch, and ambient $\mathrm{MeHg}$ concentrations averaged $0.2 \pm 0.1 \mathrm{ng} / \mathrm{g}$ dry weight in Sugar Creek and $0.7 \pm 0.2 \mathrm{ng} / \mathrm{g}$ in Warden Ditch. Sediment in the 500-mL bottles (excluding untreated reference sediment from both streams) was amended with $\mathrm{HgCl}_{2}$ dissolved in a small volume of stream water to produce sediment treatments having nominal total $\mathrm{Hg}$ concentrations of approximately $150 \mathrm{ng} / \mathrm{g}$, $800 \mathrm{ng} / \mathrm{g}, 3000 \mathrm{ng} / \mathrm{g}$, and $20000 \mathrm{ng} / \mathrm{g}$ dry weight for Sugar Creek and $500 \mathrm{ng} / \mathrm{g}, 2000 \mathrm{ng} / \mathrm{g}, 16000 \mathrm{ng} / \mathrm{g}$, and $60000 \mathrm{ng} / \mathrm{g}$ for Warden Ditch. These concentrations were selected to span a range from those typical of most freshwater sediments $(<500 \mathrm{ng} / \mathrm{g})$ to $\mathrm{Hg}$ concentrations in sediment contaminated by industrial and mining effluent [24,25]. Amounts of $\mathrm{Hg}$ (II) added to Warden Ditch sediment were greater than those added to Sugar Creek because we presumed that $\mathrm{Hg}$ (II) would be less bioavailable in the organic-rich sediment [26]. After $\mathrm{Hg}$ addition, sediment in each bottle was homogenized with a mixer for $30 \mathrm{~s}$, allowed to equilibrate for $16 \mathrm{~h}$ at room temperature, and mixed again for $30 \mathrm{~s}$ prior to loading into vials of the chemical exposure substrates. The 16-h equilibration period should have been sufficient for added $\mathrm{Hg}$ (II) to bind with natural ligands; $15 \mathrm{~min}$ was sufficient for $99 \%$ of added $\mathrm{Hg}$ (II) to adsorb to sandy (2\% loss on ignition) Long Island Sound sediment [26].

Chemical exposure substrates, consisting of a vial of sediment covered with a fritted glass disk, were prepared for each sediment type and $\mathrm{Hg}(\mathrm{II})$ treatment and incubated in Warden Ditch (Supplemental Data, Figure S1). Hinge-capped vials made of black high-density polyethylene (30-mL PolyCons $^{\circledR} ; 38 \mathrm{~mm}$ height, $38 \mathrm{~mm}$ diameter) were prepared for use as chemical exposure substrates by boring a 22-mm-diameter hole into the vial cap, and each vial was etched with a unique identification number. The vials were filled with approximately $30 \mathrm{~mL}$ of sediment and covered with a $25-\mathrm{mm}$-diameter $(4 \mathrm{~mm}$ thick) fritted glass disk secured directly to the sediment surface inside the chemical exposure substrates with the hinged cap. Fritted glass is a preferred attachment substrate for combined autotrophic and heterotrophic periphytic communities because of the durability, consistency, and cost-efficiency of fritted glass $[21,23]$. Ten replicate chemical exposure substrates were prepared for each sediment type and $\mathrm{Hg}$ treatment and attached with plastic cable ties to a plastic $L$-shaped bar ( 1 bar/treatment) secured to the bottom of Warden Ditch with steel stakes. The chemical exposure substrates were incubated with the fritted glass surface facing upward for $67 \mathrm{~d}$, from 28 June to 3 September 2013, to allow for $\mathrm{Hg}$ methylation and $\mathrm{MeHg}$ demethylation processes to reach a steady-state condition and for periphyton to colonize. Peres and colleagues [27] found that $34 \mathrm{~d}$ were sufficient for periphyton colonization of artificial substrates and that colonization continued to increase up to $71 \mathrm{~d}$. The chemical exposure substrates were arranged in the stream so that $\mathrm{Hg}$ (II) concentrations in sediment increased downstream, with approximately $0.3 \mathrm{~m}$ between each $L$-bar, to minimize potential cross-contamination among treatments. Warden Ditch was selected because it is a fen-fed, minimally disturbed headwater stream with weak and relatively consistent water flow and high water quality. These conditions allowed for the chemical exposure substrates to be deployed for an extended period during mid-summer without risk of either emergence as a result of drought or loss during extreme rain events.

Chemical exposure substrates were removed from the stream to determine $\mathrm{MeHg}$ and total $\mathrm{Hg}$ concentrations in sediment and periphyton as well as to measure periphyton organic content and metabolic activity. For each treatment, 5 of the 10 chemical exposure substrates were randomly selected a priori for analysis of $\mathrm{MeHg}$ and total $\mathrm{Hg}$ in sediment and periphyton, and the other 5 were used for analysis of periphyton metabolic activity and organic content. Periphyton for $\mathrm{Hg}$ analysis was scraped from each fritted disk with plastic spoons into plastic tubes, and sediment from each vial was transferred to plastic tubes for preservation. Samples were not composited. Periphyton and sediments were stored on ice in the field and frozen $\left(-20^{\circ} \mathrm{C}\right)$ on return to Wright State University on the day of sampling.

\section{Periphyton metabolic activity}

Periphyton metabolism and organic content were determined from the 5 chemical exposure substrates in each treatment not destructively sampled for $\mathrm{Hg}$ analysis. Net primary production and respiration of periphyton were used as parameters to assess potential $\mathrm{Hg}$ toxicity by measuring changes of dissolved $\mathrm{O}_{2}$ [28] during light-bottle and dark-bottle incubations of fritted glass disks colonized with periphyton. Immediately after removal from the stream, individual fritted glass disks were transferred to translucent 30-mL polypropylene screw-cap jars filled with stream water. Dissolved $\mathrm{O}_{2}$ and temperature were measured with a calibrated, handheld optode (YSI ProODO), and then the jars were capped and incubated under in situ temperature conditions, $10 \mathrm{~cm}$ below the water surface attached to a wire shelf (Supplemental Data, Figure S2). The jars were removed from the stream after $3.6 \mathrm{~h}$ to $4.3 \mathrm{~h}$ of incubation and opened, and dissolved $\mathrm{O}_{2}$ was measured again to quantify net primary production ([final dissolved $\mathrm{O}_{2}-$ initial $\left.\mathrm{O}_{2}\right] /$ time). Subsequently, respiration was quantified by wrapping the jars with $\mathrm{Al}$ foil, placing the jars back in the stream, and measuring dissolved $\mathrm{O}_{2}$ after an additional $2.0 \mathrm{~h}$ to $2.2 \mathrm{~h}$ of incubation in the dark ([initial dissolved $\mathrm{O}_{2}-$ final $\mathrm{O}_{2}$ ]/time). Gross primary production was not determined because net primary production and respiration could not be quantified simultaneously for the same disk. For comparison of rates of net primary production and respiration among the 2 sediment types and $\mathrm{Hg}$ treatments, rates were normalized to the organic content of periphyton colonizing fritted disks (i.e., nanomoles of $\mathrm{O}_{2}$ per milligram of organic material per hour), which was determined as described in the following section: Periphyton organic content.

\section{Periphyton organic content}

The mass of periphytic organic matter attached to the fritted glass disks was used as an endpoint to examine the toxicity of $\mathrm{Hg}$. After the final dark-bottle measurements of dissolved $\mathrm{O}_{2}$, fritted glass disks were removed from the jars containing stream water and transported on ice to Wright State University, where they were stored frozen until lyophilization. Freeze-dried fritted disks and associated periphyton were burned at $550{ }^{\circ} \mathrm{C}$ for $4 \mathrm{~h}$, with the mass difference before and after burning being a proxy for organic periphyton biomass, expressed as milligrams of organic matter per square centimeter of exposed surface area of disk.

\section{Hg determinations}

Total $\mathrm{Hg}$ and $\mathrm{MeHg}$ were measured in lyophilized sediment. Dried sediment $(0.5-1.0 \mathrm{~g})$ was accurately weighed into $60-\mathrm{mL}$ 
digestion vials, to which was added $10 \mathrm{~mL}$ of $16 \mathrm{M} \mathrm{HNO}_{3}$ and $0.5 \mathrm{~mL}$ of $\mathrm{BrCl}$ solution [29], and then digested for $6 \mathrm{~h}$ in a hot block at $95^{\circ} \mathrm{C}$. Digestates were diluted with reagentgrade water (nominal resistivity $>18 \mathrm{M} \Omega-\mathrm{cm}$ ), and total $\mathrm{Hg}$ was determined by either inductively coupled plasma mass spectrometry (ICP-MS) with a Perkin Elmer ELAN 9000 [30] or, for reference sediments, by dual-Au amalgamation cold vapor atomic fluorescence spectrometry (AFS) [31,32]. Methylmercury was extracted from separate aliquots of dried sediment $(0.25-0.50 \mathrm{~g})$ by aqueous distillation [33] and quantified by gas-chromatographic cold vapor AFS after derivatization with sodium tetraethylborate [34,35].

Freeze-dried samples of periphyton were digested with dilute $\mathrm{HNO}_{3}$ for measurement of $\mathrm{MeHg}$ and total $\mathrm{Hg}$ [36]. Briefly, periphyton $(0.03-0.25 \mathrm{~g})$ were digested with $7 \mathrm{~mL}$ of $4.6 \mathrm{~N} \mathrm{HNO}_{3}$ in a $60{ }^{\circ} \mathrm{C}$ water bath for $12 \mathrm{~h}$ prior to $\mathrm{MeHg}$ determination by gas-chromatographic cold vapor AFS. For measurement of total $\mathrm{Hg}$ in periphyton, 1-mL aliquots of the digestates were transferred to different tubes and oxidized with $0.3 \mathrm{~mL}$ of $\mathrm{BrCl}$ solution for $12 \mathrm{~h}$, and total $\mathrm{Hg}$ was quantified by dual-Au amalgamation cold vapor AFS.

\section{Quality control}

Trace-metal clean techniques were used for all sampling and analytical procedures. Experimental and analytical plasticware were cleaned with $10 \% \mathrm{HCl}$ and rinsed with reagent-grade water. Total $\mathrm{Hg}$ and $\mathrm{MeHg}$ analyses were calibrated with standard solutions traceable to the US National Institute of Standards and Technology. Certified reference material TORT2, lobster hepatopancreas (National Research Council of Canada), was digested and analyzed to assess the accuracy of analyses of $\mathrm{MeHg}$ and total $\mathrm{Hg}$ in periphyton. Sediment total $\mathrm{Hg}$ analyses included National Research Council of Canada reference material MESS-3 (marine estuarine sediment). Each digestion and distillation batch contained procedural blanks and replicate samples to assess precision and identify potential contamination.

Determinations of total $\mathrm{Hg}$ and $\mathrm{MeHg}$ in periphyton and sediment were accurate. Measured total $\mathrm{Hg}$ concentrations in MESS-3 were within their certified ranges and demonstrated no procedural bias (mean measured total $\mathrm{Hg}=94 \pm 10 \mathrm{ng} / \mathrm{g}, n=4$; certified range $=91 \pm 9 \mathrm{ng} / \mathrm{g}$ ). Procedural reproducibility of total $\mathrm{Hg}$ determinations among triplicate digestates of sediment averaged $9.2 \%$ relative standard deviation $(\mathrm{SD} ; n=2$ triplicate sets) for analysis by ICP-MS and $9.5 \%$ relative SD for 1 triplicate set analyzed by cold vapor AFS. Procedural reproducibility of sediment $\mathrm{MeHg}$ determinations averaged $8.0 \%$ relative SD among 16 triplicate sets of sample distillates. Measured $\mathrm{Hg}$ concentrations in TORT-2 also were within their certified ranges, averaging $269 \pm 11 \mathrm{ng} / \mathrm{g}$ (certified range $=270 \pm 60 \mathrm{ng} / \mathrm{g}$ ) for total $\mathrm{Hg}$ and $156 \pm 7 \mathrm{ng} / \mathrm{g}$ (certified range $=152 \pm 13 \mathrm{ng} / \mathrm{g}$ ) for $\mathrm{MeHg}$. Analytical precision of $\mathrm{MeHg}$ and total $\mathrm{Hg}$ measurements in periphyton digestates averaged $12 \%(n=8)$ and $4.4 \%(n=5)$ relative difference, respectively; procedural reproducibility of periphyton $\mathrm{Hg}$ determinations was not assessed because of the small sample sizes.

\section{Statistical analysis}

Relationships between paired variables (i.e., $\mathrm{MeHg}$, total $\mathrm{Hg}$, $\% \mathrm{MeHg}$, net primary production, respiration) were examined by least-squares linear regression analysis. Differences between Sugar Creek and Warden Ditch sediments were evaluated either by $t$ test or by Mann-Whitney rank sum test depending on whether the data were normally distributed. Differences among $\mathrm{Hg}$ treatments within each sediment type were evaluated with one-way analyses of variance (ANOVA) and Tukey's post hoc pairwise comparisons. All statistical analyses were conducted with SigmaPlot Ver 12.

\section{RESULTS AND DISCUSSION}

\section{Total $\mathrm{Hg}$ in sediment}

Measured concentrations of total $\mathrm{Hg}$ in sediment at the end of the 67-d incubation were comparable with intended nominal concentrations. Mean ( \pm SD) measured concentrations of total $\mathrm{Hg}$ in Sugar Creek sediment, from the reference to the highest $\mathrm{Hg}$ (II) treatment, were $8 \pm 1 \mathrm{ng} / \mathrm{g}, \quad 170 \pm 30 \mathrm{ng} / \mathrm{g}$, $810 \pm 140 \mathrm{ng} / \mathrm{g}, 3100 \pm 890 \mathrm{ng} / \mathrm{g}$, and $22000 \pm 3400 \mathrm{ng} / \mathrm{g}$ dry weight. Total $\mathrm{Hg}$ concentrations in Warden Ditch sediment averaged $90 \pm 5 \mathrm{ng} / \mathrm{g}, 450 \pm 60 \mathrm{ng} / \mathrm{g}, 1700 \pm 240 \mathrm{ng} / \mathrm{g}, 15000 \pm$ $4700 \mathrm{ng} / \mathrm{g}$, and $59000 \pm 27000 \mathrm{ng} / \mathrm{g}$ dry weight, from reference to the highest treatment after the incubation. Total $\mathrm{Hg}$ concentrations in the highest $\mathrm{Hg}$ (II) treatment of Sugar Creek and the 2 highest treatments of Warden Ditch sediment are comparable with those in the most $\mathrm{Hg}$-polluted aquatic systems contaminated by wastes from mining and chlor-alkali plants $[24,25]$.

\section{$\mathrm{MeHg}$ in sediment}

Methylmercury was produced in sediment, and concentrations increased with greater amounts of added $\mathrm{Hg}$ (II). At the end of the incubation period, mean $( \pm$ SD) concentrations of $\mathrm{MeHg}$ in Sugar Creek sediment were $0.2 \pm 0.1 \mathrm{ng} / \mathrm{g}$, $3.2 \pm 0.2 \mathrm{ng} / \mathrm{g}, \quad 7.6 \pm 1.0 \mathrm{ng} / \mathrm{g}, \quad 21.9 \pm 6.6 \mathrm{ng} / \mathrm{g}, \quad$ and $28.5 \pm$ $4.6 \mathrm{ng} / \mathrm{g}$ dry weight, from reference to the highest $\mathrm{Hg}$ (II) treatment. Similarly, MeHg concentrations in Warden Ditch sediment increased from reference to the highest $\mathrm{Hg}$ (II) treatment: $\quad 0.7 \pm 0.2 \mathrm{ng} / \mathrm{g}, \quad 4.1 \pm 0.5 \mathrm{ng} / \mathrm{g}, \quad 14.5 \pm 2.7 \mathrm{ng} / \mathrm{g}$, $41.3 \pm 10.1 \mathrm{ng} / \mathrm{g}$, and $101 \pm 29 \mathrm{ng} / \mathrm{g}$. Concentrations of $\mathrm{MeHg}$ in the reference of both sediment types at the end of the incubation were not significantly different from those at the start of the test ( $t$ tests, $p \geq 0.2$ ). The fraction of total $\mathrm{Hg}$ as $\mathrm{MeHg}$ (i.e., $\% \mathrm{MeHg}$ ) among all treatments of Sugar Creek sediment $(1.3 \pm 1.1 \%)$ was significantly greater than that in Warden Ditch sediment $(0.6 \pm 0.3 \%, p=0.05)$. Divalent $\mathrm{Hg}$ has a high affinity for dissolved and solid-phase organic matter, which can inhibit its bioavailability to methylating organisms and production of $\mathrm{MeHg}$ in sediment $[26,37,38]$. A greater fraction of total $\mathrm{Hg}$ as $\mathrm{MeHg}$ in Sugar Creek compared to Warden Ditch sediment suggests a greater net rate of $\mathrm{Hg}$ methylation in Sugar Creek sediment [39], which would be consistent with increased availability of $\mathrm{Hg}$ (II) substrate to methylating bacteria as a result of the lower organic content of Sugar Creek (1\% loss on ignition) sediment compared with those from Warden Ditch ( $17 \%$ loss on ignition). Gross rates of $\mathrm{Hg}$ methylation in marine sediment have been observed to vary as a function of organic content, with lower organic content sediment having greater $\mathrm{Hg}$ (II) availability and in situ methylation potentials [26,40].

Although concentrations of $\mathrm{MeHg}$ increased with total $\mathrm{Hg}$ among treatments of each sediment type, there was not a linear dose-response between $\mathrm{Hg}$ (II) added and $\mathrm{MeHg}$ produced: the fraction of total $\mathrm{Hg}$ as $\mathrm{MeHg}$ was significantly different among $\mathrm{Hg}$ treatments of Warden Ditch and Sugar Creek sediment $(p<0.001$; Figure 1). The fraction of total $\mathrm{Hg}$ as $\mathrm{MeHg}$ in the highest $\mathrm{Hg}(\mathrm{II})$ treatment of Warden Ditch sediment (total $\mathrm{Hg}=59000 \mathrm{ng} / \mathrm{g}$ ) was significantly less than that in the reference and 2 lowest $\mathrm{Hg}(\mathrm{II})$ treatments $(p<0.05)$. Likewise, 


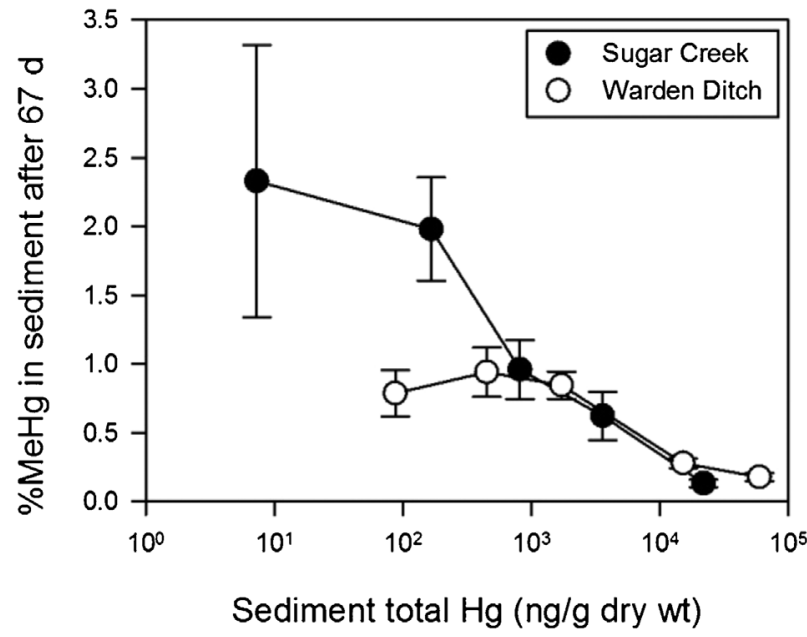

Figure 1. Variation of the fraction of total mercury $(\mathrm{Hg})$ as methylmercury $(\% \mathrm{MeHg})$ in $\mathrm{Hg}$-amended sediments from Sugar Creek and Warden Ditch after incubating in Warden Ditch for $67 \mathrm{~d}$. Error bars are \pm 1 standard deviation.

$\% \mathrm{MeHg}$ in the highest $\mathrm{Hg}$ treatment of Sugar Creek sediment (total $\mathrm{Hg}=22000 \mathrm{ng} / \mathrm{g}$ ) also was significantly less than that in the reference and lowest $\mathrm{Hg}$ treatment $(p<0.05)$. Moreover, the second highest $\mathrm{Hg}$ (II) treatment of Sugar Creek sediment (total $\mathrm{Hg}=3100 \mathrm{ng} / \mathrm{g}$ ) also contained significantly lower $\% \mathrm{MeHg}$ than the reference $(p<0.05)$. This suggests that total $\mathrm{Hg}$ concentrations between $15000 \mathrm{ng} / \mathrm{g}$ and $59000 \mathrm{ng} / \mathrm{g}$ in organicrich sediment (Warden Ditch) and between $810 \mathrm{ng} / \mathrm{g}$ and $3100 \mathrm{ng} / \mathrm{g}$ in sandy sediment (Sugar Creek) inhibit net MeHg production. When total $\mathrm{Hg}$ concentrations were normalized to sediment organic content, the concentration ranges were remarkably similar between the 2 sediment types, corresponding to $88000 \mathrm{ng} / \mathrm{g}$ to $350000 \mathrm{ng}$ of total $\mathrm{Hg}$ per gram of organic matter for Warden Ditch and $81000 \mathrm{ng} / \mathrm{g}$ to $310000 \mathrm{ng} / \mathrm{g}$ of organic material for Sugar Creek sediment. Gross potential rates of $\mathrm{Hg}$ methylation and $\mathrm{MeHg}$ demethylation are known to be rapid in sediment $[26,39,41]$, and steady-state concentrations should have been achieved within a 67-d incubation period. Accordingly, a possible explanation for decreased $\% \mathrm{MeHg}$ in the highest treatments of both sediments is that increased $\mathrm{Hg}$ (II) concentrations either were inhibitory to methylating bacteria or induced microbial transcription of mer operon genes that exacerbated demethylation [11,41], particularly the merB gene that encodes for an organomercurial lyase protein that can demethylate $\mathrm{MeHg}$. Either a slower rate of $\mathrm{Hg}$ methylation or a greater rate of $\mathrm{MeHg}$ demethylation could decrease the net production of $\mathrm{MeHg}$ (i.e., \% $\mathrm{MeHg}$ ) in sediments.

\section{$\mathrm{Hg}$ in periphyton}

Methylmercury and total $\mathrm{Hg}$ were mobilized from Sugar Creek and Warden Ditch sediment to overlying periphyton but to different degrees between the 2 sediment types. At the end of the incubation period, $\mathrm{MeHg}$ concentrations in periphyton were less than, but strongly related to, concentrations in both sediment types (Figure 2). Methylmercury concentrations in periphyton exposed to Sugar Creek sediment treatments ranged from $0.8 \mathrm{ng} / \mathrm{g}$ to $15 \mathrm{ng} / \mathrm{g}$ dry weight and were considerably greater than those in periphyton colonizing substrata above Warden Ditch sediment, which had periphyton $\mathrm{MeHg}$ concentrations ranging from $0.3 \mathrm{ng} / \mathrm{g}$ to $3.4 \mathrm{ng} / \mathrm{g}$ dry weight. Periphyton exposed to Sugar Creek sediment accumulated approximately 20 -fold more $\mathrm{MeHg}$

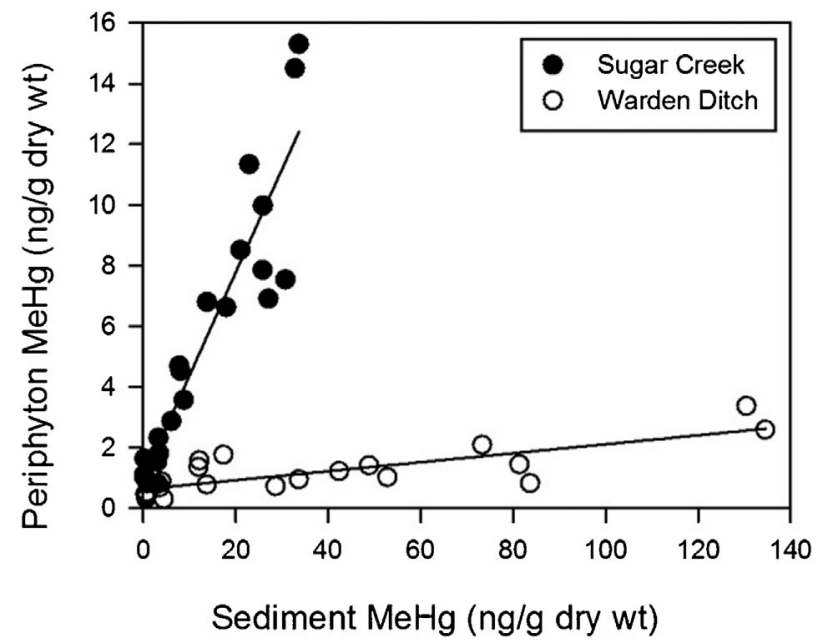

Figure 2. Methylmercury ( $\mathrm{MeHg}$ ) concentrations in periphyton colonizing chemical exposure substrates filled with $\mathrm{Hg}$-amended sediment from both Sugar Creek $\left(p<0.0001, r^{2}=0.85\right)$ and Warden Ditch $(p<0.0001$, $\left.r^{2}=0.64\right)$ relative to the concentration of $\mathrm{MeHg}$ in sediment. Slopes of regression lines are $0.34 \pm 0.03$ for Sugar Creek and $0.015 \pm 0.003$ for Warden Ditch.

than those exposed to Warden Ditch sediment, based on comparison of linear regression slopes relative to the sediment $\mathrm{MeHg}$ concentration (Figure 2). The difference of $\mathrm{MeHg}$ accumulation in periphyton between sediment types may be explained by differences in the affinity of $\mathrm{MeHg}$ for solid-phase ligands in sediment. Partitioning coefficients $\left(K_{\mathrm{D}}\right.$, liters per kilogram) of $\mathrm{MeHg}$ between sediments and pore fluids, which can range from approximately $10^{1.5}$ to $10^{3.5}$, increase with sediment organic content $[38,40,42]$. Partitioning coefficients for $\mathrm{MeHg}$ can be much greater in oxic surface water [43]. Although sediment-water partitioning of $\mathrm{MeHg}$ was not examined in the present study, a greater organic content of Warden Ditch (17\% loss on ignition) compared with Sugar Creek (1\% loss on ignition) sediment likely resulted in $\mathrm{MeHg}$ being less mobile and bioavailable to periphyton overlying Warden Ditch compared with Sugar Creek sediment. Concentrations of $\mathrm{MeHg}$ in stream periphyton in the present study were low relative to concentrations observed in Boreal Shield lakes, which ranged from $3 \mathrm{ng} / \mathrm{g}$ to $55 \mathrm{ng} / \mathrm{g}$ dry weight [14].

Concentrations of $\mathrm{MeHg}$ and total $\mathrm{Hg}$ were strongly correlated within periphyton (Figure 3); however, the ratio of $\mathrm{MeHg}$ to total $\mathrm{Hg}$ in periphyton differed between Sugar Creek and Warden Ditch sediment exposures. The mean $( \pm \mathrm{SD})$ fraction of total $\mathrm{Hg}$ as $\mathrm{MeHg}$ in periphyton overlying Sugar Creek sediment was $2.3 \pm 1.5 \%$ and significantly greater than that in periphyton above Warden Ditch sediment $(0.9 \pm 0.5 \%$; Mann-Whitney test, $p=0.003$ ). Differences of mean \% MeHg in periphyton between Sugar Creek and Warden Ditch sediment would not be expected if either uptake from stream water or in situ microbial methylation within periphyton biomass were the primary source of $\mathrm{MeHg}$ in the periphyton because both Sugar Creek and Warden Ditch chemical exposure substrates were exposed to the same stream water and presumably colonized by the same periphytic organisms. A strong relationship between $\%$ $\mathrm{MeHg}$ in periphyton and \% MeHg in both Sugar Creek and Warden Ditch sediment suggests that sediments were the primary source of MeHg accumulated by periphyton (Figure 4), rather than in situ microbial production within periphyton biomass. The slope value of the linear regression in Figure 4 is greater than unity and may result from $\mathrm{MeHg}$ being more readily 


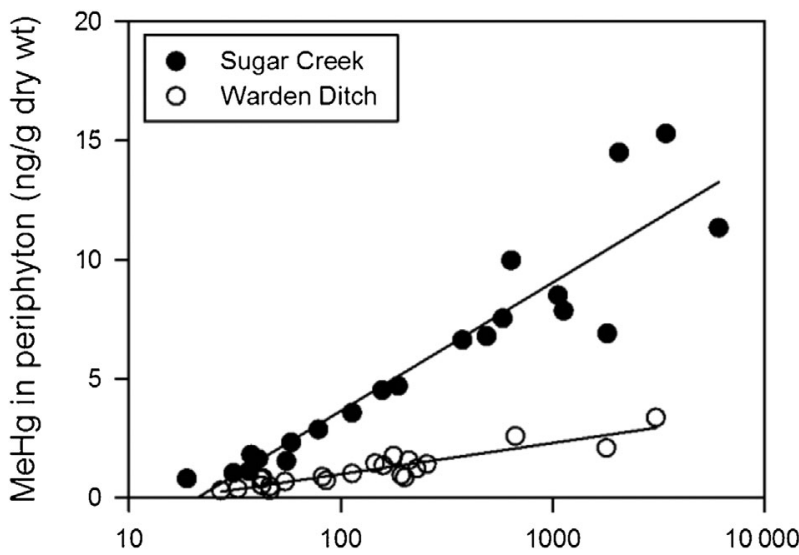

$\log$ total $\mathrm{Hg}$ in periphyton (ng/g dry wt)

Figure 3. Relationship between periphyton methylmercury (MeHg) and total $\mathrm{Hg}$ concentrations for $\mathrm{Hg}$-amended sediments from Sugar Creek $\left(p<0.001, r^{2}=0.87\right)$ and Warden Ditch $\left(p<0.001, r^{2}=0.85\right)$.

mobilized to periphyton than $\mathrm{Hg}$ (II) from underlying sediment. Alternatively, if the flux of $\mathrm{MeHg}$ and $\mathrm{Hg}$ (II) from sediment were in proportion to their ratio in sediment, a greater $\% \mathrm{MeHg}$ in periphyton compared with sediment could result from periphyton preferentially bioconcentrating $\mathrm{MeHg}$ relative to $\mathrm{Hg}(\mathrm{II})$, as has been observed for seston and plankton [2,36,44].

\section{Periphyton organic content}

The organic biomass of periphyton was examined to investigate the potential toxicity of either $\mathrm{Hg}$ (II) or $\mathrm{MeHg}$ to periphytic colonies exposed to $\mathrm{Hg}$ (II)-amended sediments (Supplemental Data, Figure S3). Among all $\mathrm{Hg}$ (II) treatments, the organic biomass of periphyton colonizing Warden Ditch chemical exposure substrates $\left(12.5 \pm 4.1 \mathrm{mg} / \mathrm{cm}^{2}\right)$ was greater than the amount of periphyton on Sugar Creek chemical exposure substrates $\left(10.2 \pm 1.9 \mathrm{mg} / \mathrm{cm}^{2}\right.$; Mann-Whitney, $p=0.03$ ). The modestly greater amount of periphytic biomass colonizing disks above Warden Ditch sediment may have resulted from greater organic matter respiration and nutrient

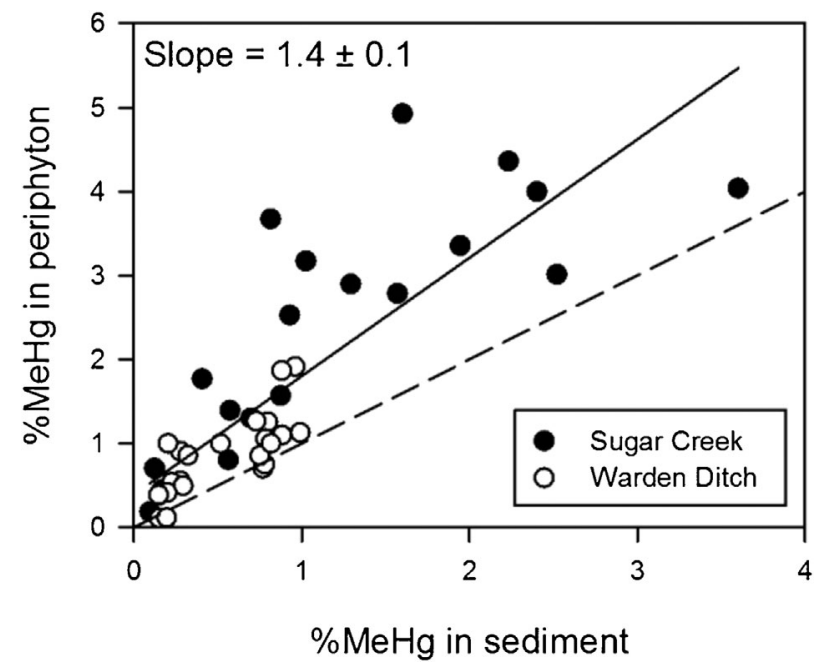

Figure 4. Linear-regression analysis (solid line) of the fraction of total $\mathrm{Hg}$ as methylmercury $(\% \mathrm{MeHg})$ in periphyton versus that in underlying $\mathrm{Hg}$ amended sediments from both Sugar Creek and Warden Ditch $(p<0.001$, $\left.r^{2}=0.69\right)$. The dashed line is the $1: 1$ reference line for comparison to the regression line. efflux from the sediment. The organic and, by extension, fixed nutrient content of Warden Ditch sediment was much greater than that of Sugar Creek deposits, so enhanced organic matter remineralization and efflux of nutrients from Warden Ditch sediment may have promoted periphyton growth.

Organic biomass of periphyton colonizing chemical exposure substrates did not differ significantly among $\mathrm{Hg}(\mathrm{II})$ treatments of either Sugar Creek sediment (ANOVA, $p=0.7$ ) or Warden Ditch sediment (ANOVA, $p=0.1$; Supplemental Data, Figure S3). A study using artificial substrates for periphyton growth found that $500 \mathrm{ng} / \mathrm{L}$ of $\mathrm{MeHg}$ had a pronounced negative effect on diatom density and species composition [27]. Moreover, exposure of marine algae to either $5000 \mathrm{ng} / \mathrm{L}$ of $\mathrm{Hg}$ (II) [45] or $100 \mathrm{ng} / \mathrm{L}$ of $\mathrm{MeHg}$ [46] resulted in a reduction of growth. In the present study, the highest $\mathrm{Hg}$ treatments had mean measured $\mathrm{MeHg}$ concentrations of $29 \mathrm{ng} / \mathrm{g}$ and $101 \mathrm{ng} / \mathrm{g}$ dry weight and total $\mathrm{Hg}$ concentrations of $22000 \mathrm{ng} / \mathrm{g}$ and $59000 \mathrm{ng} / \mathrm{g}$ in Sugar Creek and Warden Ditch sediments, respectively. We estimated porewater concentrations of both $\mathrm{MeHg}$ and $\mathrm{Hg}$ (II) based on empirical relationships between sediment-water partitioning coefficients of $\mathrm{MeHg}$ and $\mathrm{Hg}$ (II) and the organic content of sediment [42]. The maximum concentration of $\mathrm{MeHg}$ in lyophilized bulk sediment in the present study corresponded to estimated porewater $\mathrm{MeHg}$ concentrations of approximately $20 \mathrm{ng} / \mathrm{L}$ for Warden Ditch ( $17 \%$ loss on ignition) and $600 \mathrm{ng} / \mathrm{L}$ for Sugar Creek (1\% loss on ignition) and $\mathrm{Hg}(\mathrm{II})$ concentrations of approximately $120 \mathrm{ng} / \mathrm{L}$ for Warden Ditch and $12000 \mathrm{ng} / \mathrm{L}$ in Sugar Creek pore fluids, for which there was no detectable impact on periphyton biomass. Because some of the sediments were amended with $\mathrm{Hg}$ (II) to concentrations far above natural levels, periphyton may have developed a resistance to $\mathrm{Hg}$ toxicity or, more likely, only communities highly tolerant of $\mathrm{Hg}$ (II) were able to survive on the contaminated sediment in these tests.

\section{Periphyton metabolic activity}

Net primary production and respiration were measured to examine potential toxicity of $\mathrm{Hg}$ to periphyton metabolism. Many members of stream periphyton communities are primary producers and therefore photosynthesize in addition to respire. Accordingly, $\mathrm{Hg}$ toxicity could be expressed as inhibition of either net primary production (net $\mathrm{O}_{2}$ production in light bottle), respiration $\left(\mathrm{O}_{2}\right.$ consumption in dark bottle), or both. Rates of periphyton respiration were directly proportional to those of net primary production, and the slope of the linear regression between the 2 was unity (Supplemental Data, Figure S4), which suggests that gross primary production was nearly double respiration, although dark-bottle and light-bottle tests could not be conducted simultaneously with the same periphytoncolonized disk. That the community was mostly photoautotrophic is consistent with our microscopic analysis of diatoms being the dominant periphytic microorganisms colonizing the disks.

On an organic mass-normalized basis (i.e., nmol $\mathrm{O}_{2} / \mathrm{mg} / \mathrm{h}$ ), neither rates of net primary production nor respiration by periphyton colonizing fritted disks differed significantly between all combined $\mathrm{Hg}$ treatments of Sugar Creek versus all treatments of Warden Ditch sediment ( $t$ tests, $p \geq 0.4$ ). This suggests that metabolism of the periphyton was similar between the 2 sediment types. Sediment $\mathrm{Hg}$ treatments also had little or no discernable effect on periphyton metabolism (Supplemental Data, Figure S5); there were no $\mathrm{Hg}$ (II)-treatment effects for either net primary production by periphyton exposed to Warden Ditch sediment (ANOVA, $p=0.12$ ) or respiration by 
periphyton exposed to either sediment (ANOVA, $p>0.05$ ). Significant differences among $\mathrm{Hg}$ treatments were observed only for net primary production by periphyton exposed to Sugar Creek sediments (ANOVA, $p=0.01$ ), for which a Tukey post hoc comparison indicated the lowest $\mathrm{Hg}$ treatment (170 ng Hg/g dry wt) was significantly greater than the reference sediment $(8 \mathrm{ng} / \mathrm{g})$, with no significant differences among other pairwise comparisons. We interpret the difference in primary production between the low sediment and reference sediment to be an anomaly and conclude that sediment $\mathrm{Hg}$ (II) exposures used in the present study had no discernable effect on either net primary production or respiration by periphyton under the conditions and methods used in our test. The absence of $\mathrm{Hg}$ (II)-treatment effects on either net primary production or respiration may be attributed to periphyton developing a resistance to $\mathrm{Hg}$ toxicity or the fact that only communities highly tolerant of $\mathrm{Hg}$ (II) were able to survive on the chemical exposure substrates, which should be a focus of future research.

\section{Implications}

We observed that differences in the organic content of sediment had implications for the net production of $\mathrm{MeHg}$ in sediment and its availability for accumulation by stream periphyton, the dominant primary producers in many stream ecosystems [16]. Proportionately more $\mathrm{Hg}$ (II) was transformed to $\mathrm{MeHg}$ in a sandy, low-organic sediment than in a finegrained, organic-rich sediment. Moreover, and relative to the concentration of $\mathrm{MeHg}$ in sediment, periphyton accumulated approximately 20-fold more $\mathrm{MeHg}$ from the low-organic as opposed to the organic-rich sediment. Although toxicity of either $\mathrm{Hg}(\mathrm{II})$ or $\mathrm{MeHg}$ to periphyton was not observed with either of our endpoints of toxicity (periphyton organic content, net primary production, respiration), $\mathrm{MeHg}$ accumulated in periphyton in proportion to its concentration in sediment. Accumulation in periphyton increases the susceptibility for $\mathrm{MeHg}$ to be transferred to higher trophic levels in stream ecosystems because nearly all of the $\mathrm{MeHg}$ accumulated by higher aquatic organisms is from their diet $[47,48]$. The present study's results suggest that in situ production and bioaccumulation of $\mathrm{MeHg}$ in stream ecosystems can vary as a function of sediment characteristics and $\mathrm{Hg}$ loadings to the sediments.

Supplemental Data-The Supplemental Data are available on the Wiley Online Library at DOI: 10.1002/etc.3324.

Acknowledgment-We thank A. Donaldson, K. Bowman, K. Alcorn, B. Shields, D. Marsh, K. Danner, A. Agather, and R. Gamby for help in either the field or the laboratory. The present study was supported by Wright State University.

Disclaimer-The authors report no conflict of interest. The authors alone are responsible for the content and writing of the present study.

Data availability-All data, associated metadata, and calculation tools are available on request from the authors (chad.hammerschmidt@wright.edu).

\section{REFERENCES}

1. Chumchal MM, Rainwater TR, Osborn SC, Roberts AP, Abel MT, Cobb GP, Smith PN, Bailey FC. 2011. Mercury speciation and biomagnification in the food web of Caddo Lake, Texas and Louisiana, USA, a subtropical freshwater ecosystem. Environ Toxicol Chem 30:1153-1162.

2. Mason RP, Reinfelder JR, Morel FMM. 1996. Uptake, toxicity, and trophic transfer of mercury in a coastal diatom. Environ Sci Technol 30:1835-1845
3. Scheuhammer AM, Meyer MW, Sandheinrich MB, Murray MW. 2007. Effects of environmental methylmercury on the health of wild birds, mammals, and fish. Ambio 36:12-18.

4. Depew DC, Basu N, Burgess NM, Campbell LM, Devlin EW, Drevnick PE, Hammerschmidt CR, Murphy CA, Sandheinrich MB, Wiener JG. 2012. Toxicity of dietary methylmercury to fish: Derivation of ecologically meaningful threshold concentrations. Environ Toxicol Chem 31:1536-1547.

5. Mergler D, Anderson HA, Chan LHM, Mahaffey KR, Murray M, Sakamoto M, Stern AH. 2007. Methylmercury exposure and health effects in humans: A worldwide concern. Ambio 36:3-11.

6. Celo V, Lean DRS, Scott SL. 2006. Abiotic methylation of mercury in the aquatic environment. Sci Total Environ 368:126-137.

7. Benoit JM, Gilmour CC, Heyes A, Mason RP, Miller CL. 2003. Geochemical and biological controls over methylmercury production and degradation in aquatic ecosystems. In Cai Y, Braids OC, eds, Biogeochemistry of Environmentally Important Trace Elements, Vol 835-ACS Symposium Series. American Chemical Society, Washington, DC, pp 262-297.

8. Parks JM, Johs A, Podar M, Bridou R, Hurt RA ,Jr, Smith SD Tomanicek SJ, Qian Y, Brown SD, Brandt CC, Palumbo AV, Smith JC, Wall JD, Elias DA, Liang L. 2013. The genetic basis for bacterial mercury methylation. Science 339:1332-1335.

9. Gilmour CC, Podar M, Bullock AL, Graham AM, Brown SD, Somenahally AC, Johs A, Hurt ,Jr RA, Bailey KL, Elias DA. 2013. Mercury methylation by novel microorganisms from new environments. Environ Sci Technol 47:11810-11820.

10. Podar M, Gilmour CC, Brandt CC, Soren A, Brown SD, Crable BR, Palumbo AV, Somenahally AC, Elias DA. 2015. Global prevalence and distribution of genes and microorganisms involved in mercury methylation. Sci Adv 1:e1500675.

11. Barkay T, Wagner-Dobler I. 2005. Microbial transformations of mercury: Potentials, challenges, and achievements in controlling mercury toxicity in the environment. Adv Appl Microbiol 57:1-52.

12. Mauro JBN, Guimaraes JRD, Hintelmann H, Watras CJ, Haack EA, Coelho-Souza SA. 2002. Mercury methylation in macrophytes, periphyton, and water-Comparative studies with stable and radiomercury additions. Anal Bioanal Chem 374:983-989.

13. Cleckner LB, Gilmour CC, Hurley JP, Krabbenhoft DP. 1999. Mercury methylation in periphyton of the Florida Everglades. Limnol Oceanogr 44:1815-1825

14. Buckman KL, Marvin-DiPasquale M, Taylor VF, Chalmers A Broadley HJ, Agee J, Jackson BP, Chen CY. 2015. Influence of a chlor-alkali Superfund site on mercury bioaccumulation in periphyton and low-trophic level fauna. Environ Toxicol Chem 34:1649-1658.

15. Desrosiers M, Planas D, Mucci A. 2006. Total mercury and methylmercury accumulation in periphyton of Boreal Shield lakes: Influence of watershed physiographic characteristics. Sci Total Environ 355:247-258.

16. Sabater S, Guasch H, Ricart M, Romani A, Vidal G, Klunder C, Schmitt-Jansen M. 2007. Monitoring the effect of chemicals on biological communities. The biofilm as an interface. Anal Bioanal Chem 387:1425-1434.

17. Walters DM, Raikow DF, Hammerschmidt CR, Mehling MG, Kovach A, Oris JT. 2015. Methylmercury bioaccumulation in stream food webs declines with increasing primary production. Environ Sci Technol 49 7762-7769.

18. Ivorra N, Hettelaar J, Kraak MHS, Sabater S, Admiraal W. 2002. Responses of biofilms to combined nutrient and metal exposure. Environ Toxicol Chem 21:626-632.

19. DeLorenzo ME, Scott GI, Ross PE. 2001. Toxicity of pesticides to aquatic microorganisms: A review. Environ Toxicol Chem 20:84-98.

20. McCormick PV, Stevenson JR. 1998. Periphyton as a tool for ecological assessment and management in Florida Everglades. J Phycol 34:726-733.

21. Costello DM, Rosi-Marshall EJ, Shaw LE, Grace MR, Kelly JJ. 2015. A novel method to assess effects of chemical stressors on natural biofilm structure and function. Freshw Biol, in press. DOI: 10.1111/ fwb. 12641 .

22. Fairchild GW, Lowe RL, Richardson WB. 1985. Algal periphyton growth on nutrient-diffusing substrates: An in situ bioassay. Ecology 66:465-472.

23. Capps KA, Booth MT, Collins SM, Davison MA, Moslemi JM, ElSabaawi RW, Simonis JL, Flecker AS. 2011. Nutrient diffusing substrata: A field comparison of commonly used methods to assess nutrient limitation. Journal of the North American Benthological Society 30:522-532. 
24. Covelli S, Faganeli J, Horvat M, Brambati A. 2001. Mercury contamination of coastal sediments as the result of long-term cinnabar mining activity (Gulf of Trieste, northern Adriatic sea). Appl Geochem 16:541-558.

25. Ullrich SM, Ilyushchenko MA, Kamberov IM, Tanton TW. 2007. Mercury contamination in the vicinity of a derelict chlor-alkali plant. Part I: Sediment and water contamination of Lake Balkyldak and the River Irtysh. Sci Total Environ 381:1-16.

26. Hammerschmidt CR, Fitzgerald WF. 2004. Geochemical controls on the production and distribution of methylmercury in near-shore marine sediments. Environ Sci Technol 38:1487-1495.

27. Peres F, Coste M, Ribeyre F, Ricard M, Boudou A. 1997. Effects of methylmercury and inorganic mercury on periphytic diatom communities in freshwater indoor microcosms. $J$ Appl Phycol 9:215-227.

28. Bott TL, Brock JT, Baattrup-Pedersen A, Chambers PA, Dodds WK, Himbeault KT, Lawrence JR, Planas D, Snyder E, Wolfaardt GM. 1997. An evaluation of techniques for measuring periphyton metabolism in chambers. Can J Fish Aquat Sci 54:715-725.

29. Bloom NS, Crecelius EA. 1983. Determination of mercury in seawater at sub-nanogram per liter levels. Mar Chem 14:49-59.

30. Gamby RL, Hammerschmidt CR, Costello DM, Lamborg CH, Runkle JR. 2015. Deforestation and cultivation mobilize mercury from topsoil. Sci Total Environ 532:467-473.

31. Fitzgerald WF, Gill GA. 1979. Subnanogram determination of mercury by two-stage gold amalgamation applied to atmospheric analysis. Anal Chem 51:1714-1720.

32. Bloom NS, Fitzgerald WF. 1988. Determination of volatile mercury species at the picogram level by low-temperature gas chromatography with cold-vapor atomic fluorescence detection. Anal Chim Acta 208:151-161

33. Horvat M, Bloom NS, Liang L. 1993. Comparison of distillation with other current isolation methods for the determination of methyl mercury compounds in low-level environmental samples. 1. Sediments. Anal Chim Acta 298:135-152.

34. Bloom NS. 1989. Determination of picogram levels of methylmercury by aqueous phase ethylation, followed by cryogenic gas chromatography with cold vapour atomic fluorescence detection. Can J Fish Aquat Sci 46:1131-1140.

35. Tseng C-M., Hammerschmidt CR, Fitzgerald WF. 2004. Determination of methylmercury in environmental matrixes by on-line flow injection and atomic fluorescence spectrometry. Anal Chem 76:7131-7136.
36. Hammerschmidt CR, Fitzgerald WF. 2006. Bioaccumulation and trophic transfer of methylmercury in Long Island Sound. Environ Contam Toxicol 51:416-424.

37. Lamborg CH, Tseng C, Fitzgerald WF, Balcom PH, Hammerschmidt CR. 2003. Determination of the mercury complexation characteristics of dissolved organic matter in natural waters with "reducible $\mathrm{Hg}$ " titrations. Environ Sci Technol 37:3316-3322.

38. Hammerschmidt CR, Fitzgerald WF, Balcom PH, Visscher PT. 2008. Organic matter and sulfide inhibit methylmercury production in sediments of New York/New Jersey Harbor. Mar Chem 109:165-182.

39. Heyes A, Mason RP, Kim E-H., Sunderland E. 2006. Mercury methylation in estuaries: Insights from using measuring rates using stable mercury isotopes. Mar Chem 102:134-147.

40. Ogrinc N, Monperrus M, Kotnik J, Fajon V, Vidimova K, Amouroux D, Kocman D, Tessier E, Žižek S, Horvat M. 2007. Distribution of mercury and methylmercury in deep-sea surficial sediments of the Mediterranean Sea. Mar Chem 107:31-48.

41. Marvin-DiPasquale M, Agee J, McGowan C, Oremland RS, Thomas M, Krabbenhoft D, Gilmour CC. 2000. Methyl-mercury degradation pathways: A comparison among three mercury-impacted ecosystems. Environ Sci Technol 34:4908-4916.

42. Hammerschmidt CR, Fitzgerald WF. 2006. Methylmercury cycling in sediments on the continental shelf of southern New England. Geochim Cosmochim Acta 70:918-930.

43. Balcom PH, Hammerschmidt CR, Fitzgerald WF, Lamborg $\mathrm{CH}$, O'Connor JS. 2008. Seasonal distributions and cycling of mercury and methylmercury in the waters of New York/New Jersey Harbor estuary. Mar Chem 109:1-17.

44. Hammerschmidt CR, Finiguerra MB, Weller RL, Fitzgerald WF. 2013. Methylmercury accumulation in plankton on the continental margin of the northwest Atlantic Ocean. Environ Sci Technol 47:3671-3677.

45. Kuiper J. 1980. Fate and effects of mercury in marine plankton communities in experimental enclosures. Ecotoxicol Environ Saf 5:106-134

46. Harriss RC, White DB, MacFarlane RB. 1970. Mercury compounds reduce photosynthesis by plankton. Science 170:736-737.

47. Hall BD, Bodaly RA, Fudge RJP, Rudd JWM, Rosenberg DM. 1997. Food as the dominant pathway of methylmercury uptake by fish. Water Air Soil Pollut 100:13-24.

48. Tsui MTK, Wang W-X. 2004. Uptake and elimination routes of inorganic mercury in Daphnia magna. Environ Sci Technol 38: 808-816. 